\title{
What is the Impact of Savings on Growth? The Case of a Small Open Economy (Albania)
}

\section{Güngör Turan}

Ph.D, Department of Economics, Epoka University, Tirana, Albania, gturan@epoka.edu.al

\section{Olesia Gjergji}

Master Student at Banking and Finance Department, Epoka University, Tirana, Albania,

\section{Doi:10.5901/mjss.2014.v5n13p360}

\author{
ogjergji@epoka.edu.al
}

\begin{abstract}
Does economic growth come as a result of increasing the saving rate of a country? Savings and Economic Growth are closely related to each other and this is why this relationship has been subject of studies for various economists through time. The aim of this study is to indicate the causal relationship that exists between savings and economic growth in Albania between the years 1992 and 2012 (after the fall of communism, during the long transition period of the country) by implementing the Johansen Cointegration Test. According to the empirical results is revealed that savings and economic growth are cointegrated, therefore showing the existence of a stable long-run equilibrium relationship. Moreover results of the study suggest that a positive relationship between savings and economic growth and the complementary role of FDI in growth. This implies that the government must pay special attention toward FDI policies in order to positively affect Economic Growth of the country.
\end{abstract}

Keywords: Cointegration, Savings, Economic Growth, FDI

\section{Introduction}

Can a country grow faster by saving more? Actually this is the main question arising in this study.

The Solow Model shows that higher savings leads to higher growth, but only temporarily, until the economy reaches the new steady- state. Maintaining high savings rate in an economy will cause the maintenance of a high level of capital stock and high level of output, but anyway it will not maintain forever a high growth rate. By contrast a higher saving is said to have a level effect. Only the level of income per person is influenced by the saving rate in the steady state, not its growth rate.

The World Bank (1993) developed a survey regarding the effect that savings had on economic development which revealed that countries with higher saving rates had had a faster economic growth than the ones with lower saving rates. So according to the World Bank in the developing countries policies that encourage savings will also contribute to higher economic growth. However other studies results not always have supported the World Bank's results. Sinha and Sinha (1998) showed that causality goes in the opposite direction in the case of Mexico so the theory that higher savings cause higher growth does not hold in this case.

The literature regarding this topic is vast and it has a huge contribute into explaining the savings and growth relationship. Nevertheless, sometimes putting together in cross section equations countries with different specifics, experiences and different policies might sometimes result in misleading results.( Demetriades and Hussien (1996). Another problem with many other studies might also be the omission of the role that Foreign Direct Investment inflow plays in the saving and growth relationship.

The starting point of this study is to know whether the time series data of GDP, Domestic Savings and Foreign Direct Investment are stationary or non-stationary. Mishkin (1992) noted that economic series that had the presence of unit roots (non-stationary) in the dependent and independent variables resulted in no meaningful regression referred as spurious regression. So the Augmented Dickey-Fuller (ADF) tests were performed to find out whether the time series were stationary or not. After making sure to have stationary time series, the second step was that of employing the Johansen Cointegration Test. The paper investigates the causal relationship that exists between savings and growth in a small open economy like Albania and the complementary role that FDI plays on this relationship.

In order to avoid the mistakes made in some of the previous studies, the Foreign Direct Investment inflow was 
included in this study due to its growing importance. The paper intends to uncover the impact that FDls have on the relationship between savings and growth in the case of Albania. This complementary role of FDIs is studied as it can give an importance to the policies that the Government should take toward the developing strategies in the country.

As mentioned above, the main objective of this paper is to discover the relationship that exists between savings and growth in the long run in Albania. It is in this context that the study is structured in five parts. In the first part, Introduction covers the fundamental question whether by saving more a country will grow faster or not, supported by the Solow model and a survey developed by the World Bank regarding the effect that savings had on economic development. In part two of the paper is the Literature Review, chronologically showing studies made over time by other economists and specialists regarding the relation between savings and growth in their countries, and also representing what methodology they used in their studies. In this part is interesting noticing that results differ from country to country. The third part of the study includes the Data and Methodology part, explaining the period of time that is used in the study, the regression model and its determinants, and what method is used in order to discover the relationship between savings and growth in Albania. In the fourth part of the study are presented the Empirical Findings from this study. In this part are shown the results of the ADF test in order to make sure of having stationary time series, and then is performed the Johansen Cointegration Test to find out whether there exists a long term relationship between savings and growth in Albania. The very final part of the study includes the Conclusions and Implication resulting from this paper and gives the answer to our main question.

\section{Literature Review}

There are many studies that study the relationship between savings and economic growth.

Carroll and Weil (1994) found that growth Granger causes saving, but saving does not Granger cause growth. Using house- hold data they found that households with predictably higher income growth save more than households with predictably low growth. They argue that standard permanent income models of consumption cannot explain these findings, but, a model of consumption with habit formation may. The positive effect of growth on saving implies that previous estimates of the effect of saving on growth may be overstated. (Carroll, 1994) Sinha and Sinha (1998) show that the conventionally accepted view that higher saving rate causes higher economic growth does not hold for Mexico. In fact, the causality goes in the opposite direction. The conventional wisdom that higher saving rate leads to higher economic growth does not seem to bear out when careful econometric tests are performed. (Sinha, 1998). According to Andersson (1999) the causal chains linking saving and output differs across countries, and also that causality associated with adjustments to long-run relations might go in different directions than causality associated with short-term disturbances. (Anderson, 1999). Saltz (1999) explores an alternative hypothesis: that higher growth rates of GDP because increased savings. Higher growth rates of income boost the rate of savings and attract more foreign savings. The findings support the latter hypothesis in more cases. (Saltz, 1999). Sajid and Sarfraz (1999) used the Cointegration and Vector Error Correction technique to explore the causal relationship between savings and economic growth and results showed a mutual long run relationship between savings and output level. Anyway the results suggested unidirectional long run causality from public savings to output and private savings to gross national product. Savings precede the level of output in Pakistan related to long run overall results. The short run causality runs only from national savings to gross domestic product which favors the Keynesian point of view on which savings depend on level of output. Claus, Haugh, Scobie and Törnquist (2001) investigate the link between saving, investment and growth. In particular, it focuses on issues potentially important in an open economy such as New Zealand. Results showed that diversified portfolios, large inflows of foreign investment into New Zealand and investment rates comparable to those in other OECD countries suggest that New Zealand has been able to access foreign saving to meet investment demands while domestic saving does not appear to have constrained investment and hence growth. (Claus, 2001) Anoruo and Ahmad, (2001) utilized Cointegration and VECM to explore the causal relationship between economic growth and rate of domestic savings for some African Countries. They used three types of analysis: Augmented Dickey-Fuller unit root procedure, Johansen and Juselius framework and finally Granger-causality test. Results of Cointegration test suggested the existence of a long-run relationship between economic growth and growth rate of saving while results of Granger Causality test showed the contrary to conventional wisdom, economic growth causes growth rate of domestic savings for most of the countries. (Anoruo, 2001). Agrawal (2001) found that in most cases for some Asian countries, the direction of causality runs primarily from growth to savings, even though in some countries, there is as well evidence of a feedback effect from savings to growth. That is why; development policy should focus more on promoting high growth rates and less on promoting high savings rates. High savings rates in Asia are found to be due to the high rate of growth of income per capita, declining shares of dependent population, and some special institutional features, such as the high central 
provident fund rates in Singapore. Interest rates are found to have little impact on savings. (Agrawal, 2001). Romm (2003) examined the aggregate private saving rate and its interaction with investment and growth through Johansen VECM and results suggested that private saving rate has both a direct and indirect (through private investment rate) effect on growth while growth has a positive effect on private saving rate. Growth enhances savings which in turn further enhances growth. (Romm, 2003). Alguicil, Cuadros and Orts (2004) presented evidences in favor of Solow's model prediction that higher savings lead to higher economic growth as opposition to the reverse causation between national savings and domestic income found in recent empirical studies. The inclusion of Foreign Direct Investment in the model confirms the saving-growth nexus and it enhances economic growth and reinforces the connection between savings and growth. (Alguacil, 2004). Adebiyi (2005) concluded from his research regarding saving and growth causal relationship for Nigeria that the evidence from impulse response analysis and Granger causality tests show that growth, using per capita income, is sensitive to, and has an inverse effect on savings. (Adebiyi, 2005). Mohan (2006) studied relationship between domestic savings and economic growth for various economies with different income levels. The study favors the hypothesis that the causality is from economic growth rate to growth rate of savings. Based on the empirical results, the main conclusion of this study is that income class of a country does play an important role in determining the direction of causality. (Mohan, 2006). Lean and Song (2008) examined the relationship between growth and domestic savings and economics in China and found that economic growth in China is found to be cointegrated with two other variables: household saving and enterprise saving growth. In the short run a bilateral causality exists between household saving growth and economic growth, while in long run a unidirectional causality exists from economic growth to the enterprise saving growth. (Lean, 2008). Aghion, Comin, Howitt and Tecu (2009) in their theoretical model, growth resulted from innovations that allow sectors to catch up with frontier technology. In poor countries where catching up requires cooperation of a foreign investor and a domestic entrepreneur, domestic savings matter for innovation and therefore growth because it enables the local entrepreneur to put equity into the problem that would otherwise deter the foreign investor from participating. In rich countries domestic saving do not matter for growth as the domestic entrepreneurs are familiar with frontier technology leading to no need to attract foreign investors. According to a cross country regression is shown that remaining savings is positively related to productivity growth in poor countries but not same situation is in rich countries. (Aghion, 2009). AbuAl-Foul (2010) studied the long run relationship between real gross domestic product and real gross domestic savings for Morocco and Tunisia and results revealed that in case of Morocco there exists a long run relationship between the variables based on Granger Casuality test while there is no evidence of long-run relationship in the case of Tunisia. (AbuAl-Foul, 2010). Olapido (2010) used Toda and Yamamoto and Dolado and Lutkepohl - TYDL methodology to discover the causal relationship between savings and economic growth in Nigeria and results suggested that savings and economic growth are positively cointegrated indicating a stable long run equilibrium relationship. Moreover the findings showed a unidirectional causality between savings and economic growth and the complementary role of FDI in growth. (Olapido, 2010). (AbuAl-Foul, 2010)

\section{Data and Methodology}

In order to examine the casual relationship between savings and economic growth in Albania, this study employs annual data from 1992 to 2012 so for a 20 year period. Data for this research are obtained from Central Bank of Albania (BoA), the World Bank (WB) and Index Mundi. Domestic Income is shown through GDP while domestic saving and foreign direct investment are presented as percentages of GDP.

In Figure 1 is shown a graphical scatter plot representation of domestic saving and foreign direct investment in relation to Gross Domestic Product (GDP). As the graph shows the relationship is not spurious so it can be understood that a causal relation exists between GDP domestic savings and FDI. While on Figure 2 is shown the line graph where it is noticed that the variables go on together, but from time to time there are some fluctuations. 


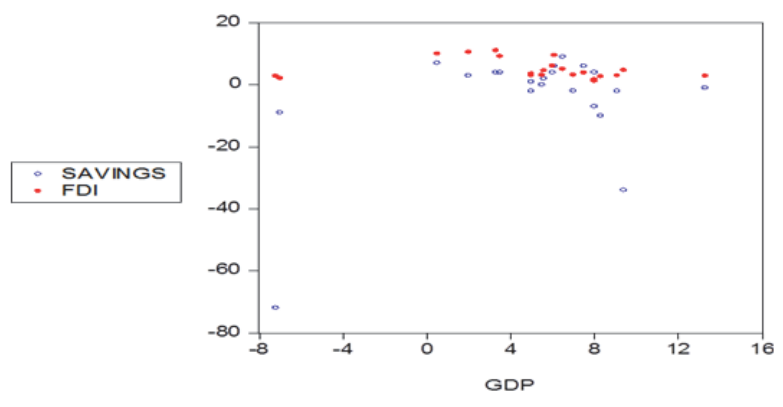

Figure 1: Scatter plot representing GDP, Savings and FDI

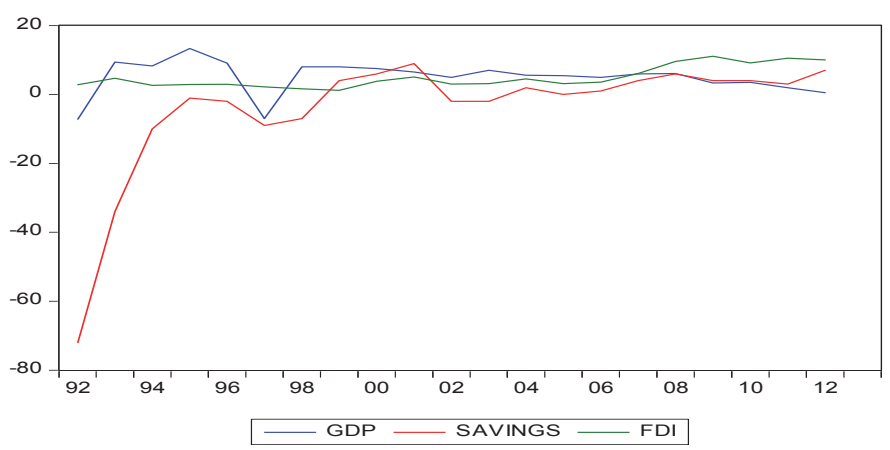

Figure 2: Line graph representing GDP, Savings and FDI

In the first stage of the study is applied the Augmented Dickey-Fuller (ADF) test at $1 \%$ level of significance in order to make sure that the series used in the model are stationary time series otherwise the results might not hold much meaning Before performing the Johansen Cointegration test, is shown the regression model of the study.

The regression model performed in this study is:

$$
G D P=\alpha+\beta_{1} S a v+\beta_{2} F D I+e
$$

Where: $\alpha$ : is the intercept

$\beta_{1}$ and $\beta_{2}$ are the estimated regression coefficients

$\mathrm{e}:$ is the error term

GDP: Gross Domestic Product is the dependent variable

Sav: Domestic Savings is the independent variable

FDI: Foreign Direct Investment is the independent variable.

Hypothesis:

Ho: Domestic Savings and FDI have a positive effect on Economic Growth in the long run.

Hi: Domestic Savings and FDI don't have a positive effect on Economic Growth in the long run.

Moreover in order to determine whether there exists a long run relationship among domestic saving, foreign direct investment and economic growth expressed as GDP the Johansen Cointegration Test is performed. In order to have a relationship between the variables the Trace Statistic must be greater than $5 \%$ critical value. Also the maximum eigenvalue test must be greater than $5 \%$ critical value.

\section{Empirical Findings}

In Table 2 and as well in Figure $3(a, b$ and $c)$ are shown the group statistics performed in order to test the distribution of data. After checking the Skewness and Kurtosis for all the three the variables, due to the presence of unit root on the variables the results showed to be asymmetric and not in a bell shaped. In all the three variables data neither the Skewness was close to zero nor was the Kurtosis near to 3. 
Table 1. Group Statistics

\begin{tabular}{|l|c|c|c|}
\hline & GDP & SAVINGS & FDI \\
\hline Mean & 5.019048 & -4.238095 & 4.951905 \\
\hline Median & 6.000000 & 1.000000 & 3.560000 \\
\hline Maximum & 13.30000 & 9.000000 & 11.08000 \\
\hline Minimum & -7.200000 & -72.00000 & 1.200000 \\
\hline Std. Dev. & 4.881047 & 18.00807 & 3.157293 \\
\hline Skewness & -1.256532 & -2.884593 & 0.880233 \\
\hline Kurtosis & 4.565131 & 10.96401 & 2.289625 \\
\hline & & & \\
\hline Jarque-Bera & 7.669482 & 84.62031 & 3.153387 \\
\hline Probability & 0.021607 & 0.000000 & 0.206657 \\
\hline & & & \\
\hline Sum & 105.4000 & -89.00000 & 103.9900 \\
\hline Sum Sq. Dev. & 476.4924 & 6485.810 & 199.3699 \\
\hline & & & 21 \\
\hline Observations & 21 & 21 & \\
\hline
\end{tabular}

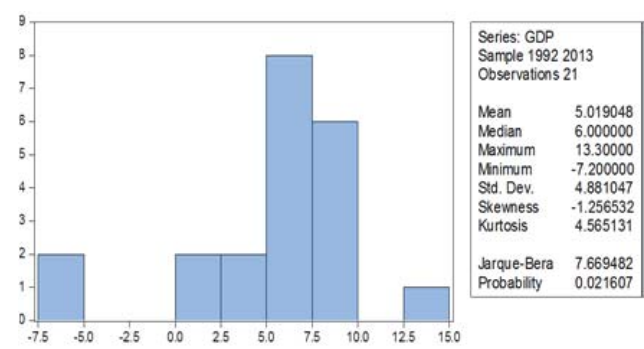

Figure 3 (a) GDP
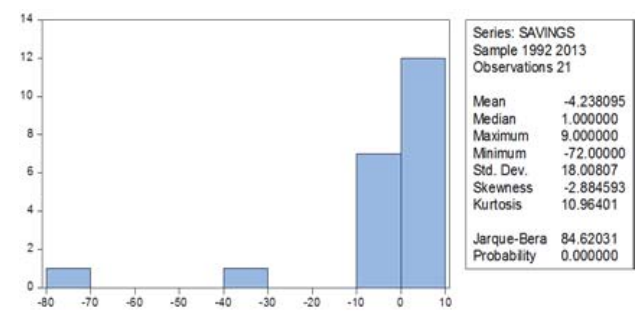

Figure 3 (b) Savings

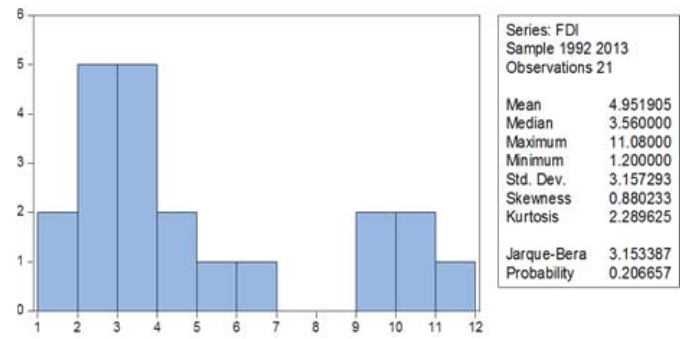

Figure 3 (c) FDI 
In order to examine whether the series were stationary time series Augmented Dickey-Fuller (ADF) test was performed. First result showed that for GDP, Domestic Savings or FDI the null hypothesis "GDP, Domestic Savings or FDI have a unit root" was not rejected as at $1 \%$ critical values since the calculated t-statistics for the three of them were greater than the $1 \%$ of critical value. So according to these results the presence of unit roots in the underlying series points toward the non-stationary of the underlying series. As the dependent and independent variables show the presence of unit roots this means that the results of the regression do not hold much meaning.

Table 2. ADF tests for GDP, Savings and FDI

Null Hypothesis: GDP has a unit root

Exogenous: Constant

Lag Length: 1 (Fixed)

\begin{tabular}{lccc}
\hline \hline & & t-Statistic & Prob. $^{*}$ \\
\hline \hline Augmented Dickey-Fuller test statistic & & -3.390511 & 0.0246 \\
\hline Test critical values: & $1 \%$ level & -3.831511 & \\
& $5 \%$ level & -3.029970 & \\
& $10 \%$ level & -2.655194 & \\
& & & \\
\hline \hline
\end{tabular}

Null Hypothesis: SAVINGS has a unit root

Exogenous: Constant

Lag Length: 1 (Fixed)

\begin{tabular}{cccc}
\hline \hline & t-Statistic & Prob. \\
& & & \\
\hline \hline Augmented Dickey-Fuller test statistic & -3.726737 & 0.0124 \\
\hline Test critical values: & $1 \%$ level & -3.831511 & \\
& $5 \%$ level & -3.029970 & \\
& $10 \%$ level & -2.655194 & \\
& & & \\
\hline \hline
\end{tabular}

Null Hypothesis: FDI has a unit root

Exogenous: Constant

Lag Length: 1 (Fixed)

\begin{tabular}{lccc}
\hline \hline & & t-Statistic & Prob. $^{*}$ \\
\hline \hline Augmented Dickey-Fuller test statistic & & -0.546258 & 0.8610 \\
\hline Test critical values: & 1\% level & -3.831511 & \\
& $5 \%$ level & -3.029970 & \\
& $10 \%$ level & -2.655194 & \\
\hline \hline
\end{tabular}

*MacKinnon (1996) one-sided p-values.

Warning: Probabilities and critical values calculated for 20 observations

and may not be accurate for a sample size of 19

This is why in order to have the indispensable stationary time series and to reject the hypothesis that the variables have a unit root, another Augmented Dickey-Fuller Unit Root test is performed by performing the first difference on the variables needed so that the regression to be meaningful. 
Table 3. ADF test after taking the first difference for GDP, Savings and FDI

Null Hypothesis: D(GDP) has a unit root

Exogenous: None

Lag Length: 0 (Fixed)

\begin{tabular}{llcc}
\hline \hline & & t-Statistic & Prob. $^{*}$ \\
\hline \hline Augmented Dickey-Fuller test statistic & & -6.970467 & 0.0000 \\
\hline Test critical values: & 1\% level & -2.692358 & \\
& 5\% level & -1.960171 & \\
& $10 \%$ level & -1.607051 & \\
& & & \\
\hline \hline
\end{tabular}

Null Hypothesis: D(SAVINGS) has a unit root

Exogenous: None

Lag Length: 0 (Fixed)

\begin{tabular}{lccc}
\hline \hline & & t-Statistic & Prob. $^{*}$ \\
\hline \hline & & & \\
Augmented Dickey-Fuller test statistic & 1\% level & -5.051230 & 0.0000 \\
\hline Test critical values: & 5\% level & -1.692358 & \\
& $10 \%$ level & -1.607051 & \\
& & & \\
\hline \hline
\end{tabular}

Null Hypothesis: $D(F D I)$ has a unit root

Exogenous: None

Lag Length: 0 (Fixed)

\begin{tabular}{llll}
\hline \hline & & t-Statistic & Prob. $^{*}$ \\
\hline \hline Augmented Dickey-Fuller test statistic & & -4.221336 & 0.0003 \\
\hline Test critical values: & 1\% level & -2.692358 & \\
& 5\% level & -1.960171 & \\
& $10 \%$ level & -1.607051 & \\
\hline \hline
\end{tabular}

*MacKinnon (1996) one-sided p-values.

Warning: Probabilities and critical values calculated for 20 observations

and may not be accurate for a sample size of 19

The final step after performing the First Difference of the Augmented Dickey-Fuller Unit Root Test and finally having stationary time series is the application of Johansen Cointegration test in order to study whether there is a long term relationship between the variables. According to the test results it is suggested that there exists a Cointegration relation between variables as long as Trace Statistics (43.759) is greater than $5 \%$ Critical Value (29.797). Also by looking at the Maximum Eigenvalue test the max eigenvalue statistic (28.951) is greater than $5 \%$ Critical Value (21.131). 
Table 4. Johanson Cointegration Test

Unrestricted Cointegration Rank Test (Trace)

\begin{tabular}{lcccc}
\hline \hline $\begin{array}{c}\text { Hypothesized } \\
\text { No. of CE(s) }\end{array}$ & Eigenvalue & $\begin{array}{c}\text { Trace } \\
\text { Statistic }\end{array}$ & $\begin{array}{c}0.05 \\
\text { Critical Value }\end{array}$ & Prob.** \\
\hline \hline None * & & & \\
At most 1 & 0.782109 & 43.75952 & $>29.79707$ & 0.0007 \\
At most 2 & 0.535121 & 14.80810 & 15.49471 & 0.0633 \\
& 0.013306 & 0.254520 & 3.841466 & 0.6139 \\
\hline \hline
\end{tabular}

Trace test indicates 1 cointegrating eqn(s) at the 0.05 level

* denotes rejection of the hypothesis at the 0.05 level

**MacKinnon-Haug-Michelis (1999) p-values

\section{Unrestricted Cointegration Rank Test (Maximum Eigenvalue)}

\begin{tabular}{lcccc}
\hline \hline $\begin{array}{c}\text { Hypothesized } \\
\text { No. of CE(s) }\end{array}$ & Eigenvalue & $\begin{array}{c}\text { Max-Eigen } \\
\text { Statistic }\end{array}$ & $\begin{array}{c}0.05 \\
\text { Critical Value }\end{array}$ & Prob. ** $^{*}$ \\
\hline \hline None * $_{\text {At most 1 }}^{*}$ & 0.782109 & 28.95142 & $>21.13162$ & 0.0032 \\
At most 2 & 0.535121 & 14.55358 & 14.26460 & 0.0450 \\
& 0.013306 & 0.254520 & 3.841466 & 0.6139 \\
\hline \hline
\end{tabular}

Max-eigenvalue test indicates 2 cointegrating eqn(s) at the 0.05 level

* denotes rejection of the hypothesis at the 0.05 level

**MacKinnon-Haug-Michelis (1999) p-values

In other words a long run stable relationship exists between Domestic Savings, FDI and GDP and they move together in the long run. So a causal relation exists between Domestic Savings, Foreign Direct Investment and Gross Domestic Income. The increase of Savings and FDI enhances Economic Growth in Albania.

\section{Conclusions and Implications}

In this paper is presented the causal relationship that exists between domestic savings and economic growth through the Johansen Cointegration Test. The empirical results showed that a stable long relationship exists between savings and economic growth. In the study was also included the FDI and the complementary role that it plays in economic growth. As economic growth is very important for Albania, the government must pay special attention to the formulation of specific policies in order to attract foreign direct investments in the country which would also enhance savings and promote economic growth as well.

\section{References}

AbuAl-Foul,B. (2010) Casual Relation between Savings and Economic Growth: Some Evidence from MENA Countries.MEEA Meeting. Adebiyi (2005) Saving-Growth relationship in Nigeria: An Empirical Evidence. African Review of Money Finance and Banking, 159-178 Aghion,P., Comin,D., Howitt,P. and Tecu,I (2009) When does Domestic Saving Matter for Economic Growth. NBER Working Paper No. 12275

Agrawal, P. (2001) The relation between Savings and Growth: Cointegration and Causality Evidence from Asia, Applied Economics, 33, 499-513.

Alguacil, M., Cuadros, A. and V. Orts (2004) Does Saving really matter for Growth? Mexico (1970-2000). Journal of International Development, March, 16, 2: 281-290.

Anderson, B. (1999), On the Causality between Saving and Growth: Long and Short Run Dynamics and Country Heterogeneity. Department of Economics, Uppsala University, Sweden.

Anoruo, E and Ahmad, Y (2001) Causal Relationship between Domestic Savings and Economic Growth: Evidence from Seven African Countries, African Development Bank, Blackwell publisher, Oxford. 
Carroll, C. D., and D. N. Weil (1994): "Saving and Growth: A Reinterpretation," Carnegie-Rochester Conference Series on Public Policy, 40, 133-192.

Claus,I., Haugh,D., Scobie,G. and Törnquist, J. (2001) Saving and Growth in an Open Economy. Treasury Working Paper. $01 / 32$.

Demetriades, P and Hussien, K (1996) Does Financial Development Cause Economic Growth: Time Series Evidence from 16 Countries. Journal of Development Economics, Vol. 51, No. 2, 387-411.

Lean, H., and Song, Y. (2008) Domestic Saving and Economic Growth in China. Asian Business and Economics Research Unit. Discussion Paper 64, 2008

Mankiw, N.G.,( 2012) "Macroeconomics", Harvard University.

Mishkin, Frederic S.,( 1992) "Is the Fisher effect for real? : A reeaxamination of the relationship between inflation and interest rates," Journal of Monetary Economics.

Mohan, R. (2006) Causal Relationship between Savings and Economic Growth in Countries with different Income Levels. Economic Bulletin, Vol. 5, No. 3: 1-12.

Olapido,O.S., (2010) Does Saving really matter for Growth in Developing Countries? The Case of a Small Open Economy. The Clute Institute International Business \& Economics Research Journal. Vol 9, No 4 (2010).

Romm,A. T., (2003) The Relationship between Savings and Growth in Africa: An Empirical Study. TIPS/ DPRU Forum.

Sajid,G.M. and Sarfraz,M.,(1999) Savings and Economic Growth in Pakistan: An Issue of Causality. Pakistan Economic and Social Review. Volume 46, No.1. pp. 17-36.

Saltz, I. S. (1999), An examination of causal relationship between savings and growth in the Third World. Journal of Economics and Finance,Volume 23, No. 1, pp. 90-98.

Sinha, D. and T. Sinha (1998), Cart before the horse? The saving growth nexus in Mexico. Economics Letters, Volume 61, pp. 43-47.

Solow, R.M; 1956, "A Contribution to the Theory of Economic Growth"; Quarterly Journal of Economics, 70(1), 65-94.

World Bank (1993) The East Asian Miracle: Economic Growth and Public Policy, New York: Oxford University Press. 